\title{
Do Postsecondary Internships Address the Four Learning Modes of Experiential Learning Theory? An Exploration through Document Analysis
}

Ashley Stirling, Gretchen Kerr, Ellen MacPherson, Jenessa Banwell, Ahad Bandealy, and Anthony Battaglia University of Toronto

\begin{abstract}
The educational benefits of embedding hands-on experience in higher education curriculum are widely recognized (Beard \& Wilson, 2013). However, to optimize the learning from these opportunities, they need to be grounded in empirical learning theory. The purpose of this study was to examine the characteristics of internships in Ontario colleges and universities, and to assess the congruence between the components of these internships and Kolb's (1984) experiential learning framework. Information from 44 Ontario universities and colleges, including 369 internship program webpages and 77 internship course outlines, was analyzed. The findings indicated that internship programs overemphasize the practical aspect of the experience at the expense of linking theory and practice. To optimize experiential education opportunities, recommendations include establishing explicit learning activities consistent with each experiential learning mode, including practice, reflection, connecting coursework and practical experience, and implementing creative ideas in practice.
\end{abstract}

\section{Résumé}

Les avantages éducatifs de l'intégration d'une expérience pratique au sein du curriculum de l'éducation supérieure sont grandement reconnus (Beard et Wilson, 2013). Toutefois, afin d'optimiser les occasions d'apprentissage, celles-ci doivent être basées sur des théories d'apprentissage empiriques. Le but de cette étude était d'examiner les caractéristiques des stages dans des 
collèges et universités de l'Ontario, ainsi que d'évaluer la corrélation entre les composantes de ces stages et le cadre de travail de l'apprentissage par l'expérience selon Kolb (1984). L'information provenant de 44 universités et collèges ontariens, incluant les sites Internet de 369 programmes de stage et les plans de cours de 77 stages, a été analysée. Les résultats indiquent que les programmes de stage insistent trop sur les aspects pratiques de l'expérience plutôt que de lier la théorie à la pratique. Afin d'optimiser les possibilités éducatives d'apprentissage, les recommandations comprennent l'établissement d'activités d'apprentissage explicites qui soient compatibles avec chaque modèle d'apprentissage par l'expérience, incluant la pratique, la réflexion, des travaux liés à l'expérience pratique, et la mise en œuvre d'idées créatives dans la pratique.

\section{Introduction}

The importance of integrating students' classroom learning with real-world practical experience has been recognized as a vital component of student engagement and development in higher education (Kuh, 2008). Postsecondary institutions have responded by incorporating various forms of work-integrated learning opportunities including internships, practica, cooperative education, placements, and apprenticeships. Currently, there are over 580,000 full-time students enrolled in postsecondary education in Ontario (Hicks, Weingarten, Jonker, \& Liu, 2013; Weingarten, Hicks, Jonker, \& Liu, 2013). Recent research conducted by the Higher Education Quality Council of Ontario on the interest in and participation of Ontario postsecondary students in work-integrated learning opportunities indicated that $47.6 \%$ of students in direct-entry postsecondary programs will have completed a work-integrated learning experience by the time of graduation (Sattler \& Peters, 2013). This does not take into account the vast number of work-integrated learning opportunities offered by second-entry and graduate programs.

Student internships, the focus of this study, are an increasingly common experience for postsecondary students (Hergert, 2009). They have been recognized as an effective way to bridge classroom learning with professional practice (Baird, 1996; Paris \& Adams, 1994) and have been referred to as an integral aspect of educational and professional development (Jowdy, McDonald, \& Spence, 2004; Schmutte, 1986). Although numerous authors have provided definitions of what an "internship" may constitute relative to institutional practice (Moore, 2010), study parameters (Alpert, Heaney, \& Kuhn, 2009; Gault, Leach, \& Duey, 2010), or a global typology of work-integrated learning (Sattler, 2011), no standard definition of "internship" exists. There is however, consensus among all the definitions proposed in the extant literature that internships are meant to be educational and should provide structured, meaningful, and career-relevant experiences for students. Despite these points of consistency, discrepancies exist regarding the suggested time commitments (e.g., full time or part time, duration of internship), compensation (e.g., paid or unpaid), and the specific academic requirements of students who engage in internships (e.g., timing of internship in academic program, opportunity for course credit). In addition to the different definitions of internship, it is notable that they are not always clearly distinguished from other work-integrated learning opportunities, such as cooperative education, apprenticeships, placements, and practica. 
Although the definition of internship remains unclear, they are viewed as beneficial for all parties-the student, institution, and employer-as they are believed to provide hands-on practical experience (Baird, 1996; Kuh, 2008; Paris \& Adams, 1994), solidify knowledge learned in the classroom (Sattler, 2011; Schmutte, 1986), impart career exploration and preparation (Gault et al., 2010; Sattler, 2011), enhance an individual's understanding of personal characteristics (Tovey, 2001), build stronger resumes (Coco, 2000; Divine, Linrud, Miller, \& Wilson, 2007), and introduce up-to-date knowledge and new ideas within organizations (Knemeyer \& Murphy, 2002; Sattler, 2011; Thiel \& Hartley, 1997). Despite these reported benefits, however, numerous challenges associated with internships have been cited, including effective transfer of student learning from educators to practitioners (Ciofalo, 1992; Kolb, 1984; Tovey, 2001), administrative challenges (Sattler, 2011), insufficient funding (Sattler, 2011; Schmutte, 1986), legal considerations (Moorman, 2004), student involvement in meaningless tasks, and lack of stakeholder interest (Schmutte, 1986).

Of greatest importance, challenges exist in ensuring that internships are educational for students. It is far too easy to assume that all experiences are educational when in fact this is far from the truth (Moore, 2010). The media, in particular, have identified numerous cases in which students are exploited through unpaid work and engagement in meaningless tasks, such as running for coffee and cleaning toilets (McKnight, 2013). For the potential benefits to be gleaned from the internship experience for all stakeholders, it is essential that internships are of high educational quality. And, to optimize the potential educational and developmental benefits from internship experiences, it is important that they are grounded in empirical learning theory.

Several learning theories are used in work-integrated learning environments and may be applied to higher education internship programming, including experiential learning theory (Kolb, 1981; 1984), situated learning theory (Lave \& Wagner, 1991), action theory and boundary crossing (Guile \& Griffiths, 2001), pedagogy of the workplace (Billett, 1996; 2002; 2011), and critical education theory (Myers-Lipton as cited in Sattler, 2011; Keating, 2006). For the purposes of this research, Kolb's (1981; 1984) experiential learning theory was used because it is well recognized in higher education settings (Kelly, 1997) and has been highly regarded for raising awareness of experiential learning as a critical aspect of postsecondary education (Brookfield, 1990; Jarvis, 1995; Kemp, Morrison, \& Ross, 1996; McKeachie, 1994).

Kolb's (1981; 1984) experiential learning theory, which is rooted in the work of Dewey (1938), Lewin (1951) and Piaget (1971), is holistic in nature and focuses on the affective, perceptive, cognitive, and behavioural dimensions of the learner. Learning, according to Kolb, is a four-stage cycle consisting of concrete experience (feeling dimension), reflective observation (reflecting/watching dimension), abstract conceptualization (thinking dimension), and active experimentation (doing dimension). Each stage provides the basis for the subsequent learning stage; learners can enter the cycle at any stage but need the abilities represented by all of the stages for learning to be most effective (Evans, Forney, Guido, Patton, \& Renn, 2010; Kolb, Boyatzis, \& Mainemelis, 2001). According to Kolb (1984), educational approaches that fail to address each stage in this learning cycle fall short of meeting the conditions required for optimal learning. 
This theory is widely applied to higher education frameworks and developments (Cantor, 1997; Healey \& Jenkins, 2000; Hopkins, 1999; Kolb \& Kolb, 2005; Kuh, 2008; Lempert, 1996; Priest \& Gass, 1997). Although commonly used, experiential learning theory has been criticized for its proposed stage-based approach to learning. By not recognizing that multiple learning processes may occur at one time (Seaman, 2008), it does not consider the goals, purposes, and intentions of the learner (Rogers, 1996). The theory also fails to consider the influence of power relations (Vince, 1998) and the social, cultural, and historical aspects of the learner (Beard \& Wilson, 2013). Despite these contentions, given the relevance of the learning theory to the integration of student classroom learning with real-world practical experience and its pervasive use in higher education settings (Moore, 2010), experiential learning theory applies well to student internship programming in postsecondary institutions.

Given the challenge of assuring internships of high educational quality, it is critical to examine the current conditions of internships and the extent to which they are consistent with experiential learning theory. The purpose of this research study, therefore, was to conduct a document analysis of the characteristics of internships in Ontario colleges and universities as portrayed in internship course outlines and to assess the congruence between the components of the various internships and experiential learning theory (Kolb, 1984). The broader intention of this research was to conduct an exploratory investigation of whether postsecondary internships meet acknowledged standards of experiential learning, following the learning modes of Kolb's experiential learning cycle. We recognized that internship web content and shared course outlines may not fully reflect all pedagogical practices of the internship programs. However, previous literature on the use of web-based information by higher education institutions has suggested that the information selected for inclusion on an institution's webpage is intended to reflect institutional quality, values, and distinctiveness (Meyer \& Wilson, 2010). Furthermore, the use of course outlines as an information source has been commonly used in previous higher education studies (Bontis, 1999; Dunn, 2015; Venkateswarlu, 2002). As such, a document analysis of this information is useful in developing a preliminary picture of postsecondary internship programming and provides a basis for further pedagogical inquiry, articulation, and consideration.

At the time this research was conducted there was a lot of media and policy attention in Ontario on the defining characteristics of postsecondary internships, such as length, compensation, and type of student work (McKnight, 2013; Sattler, 2011). It is our supposition however, that the purpose of postsecondary internships offered within higher education institutions should be educational in focus, and from an educational perspective, the educational quality of postsecondary internships is the question of utmost important. Consistent with this viewpoint, the purpose of this research was to assess the educational quality of Ontario postsecondary internships. Attending to both practical and pedagogical perspectives, in this research, both descriptive characteristics and educational qualities of postsecondary internships were assessed through document analysis. This was an exploratory study that sheds light on a number of areas upon which a future research agenda could be built. 


\section{Methods}

To address the research purpose, a two-part research design was employed: part one was a web-based analysis, and part two was an analysis of internship program outlines. Each will be described in turn.

\section{Part I: Web-based Analysis}

A web-based analysis was conducted of all learning opportunities labelled as internships that were currently posted online and were facilitated for students enrolling in firstentry postsecondary education programs in Ontario colleges and universities. A webbased approach was chosen because the Internet is critical to universities and colleges for establishing a strong presence to the public through its communication of information about the institution's products, values, goals, and unique characteristics (Swan \& Carr, 2008). The Internet has also been supported as a medium for content-analysis research (McMillan, 2000; Neuendorf, 2002; Weare, 2000).

Data collection began by searching the available student internship opportunities posted online for first-entry postsecondary programs facilitated through the 20 provincially funded universities and 24 provincially funded colleges in Ontario. For the purpose of this research, data were recorded regarding all available opportunities that were labelled as an internship. This search did not include other student work-integrated learning opportunities that were not specifically identified as an internship, such as service-learning courses, placements, practicums, cooperative experiences, etc.

For each student-internship program identified on an institutional webpage, we recorded the organization, internship prerequisites, conditions, any associated fees, compensation, roles and responsibilities, intended outcomes, educational conditions, whether or not the internship was a requirement of the academic program, and contact information for the program administrator. In order to assure trustworthiness in this phase of the research, data collection and analysis occurred amongst a group of six research team members. Prior to beginning the research, all members of the research team were trained to create data categorization themes, and they learned procedures for identifying and documenting the web content. Research team members met weekly to discuss the data collection and identify new themes in order to ensure consistency in data collection and categorization practices among the researchers. The collected information then was analyzed inductively as a group and the content was organized into summary tables. The final step in this phase of the research was to run a descriptive analysis of the recorded content.

\section{Part II: Analysis of Internship Program Outlines}

To supplement the web-based analysis, a second phase of data collection and analysis was conducted, which included collecting outlines for the internship programs. In Part I, contact information for the administrators of 167 internship programs was recorded. This contact list is shorter than the total number of internship programs because some programs did not provide contact information online. Emails were distributed to each identified administrator on an individual basis, and follow-up emails were sent one week apart for three consecutive weeks. The email requested that administrators provide a course and/or program outline for the student internship program in question. 
In total, information for 77 internship programs were collected from a variety of disciplines including biology, commerce, economics, engineering, earth and environment studies, heavy construction, photography, radio studies, recreation therapy, women and gender studies, and visual arts, among others. A content analysis was conducted of all program outlines, looking specifically at the intended learning outcomes of each internship program and the educational components included (e.g., required course assignments, on-site expectations, presentations, etc.).

Krippendorff (2012) defines content analysis as "an empirically grounded method, exploratory in process, and predictive or inferential in intent" (p. 1). In this study, a confirmatory thematic approach was employed for the analysis of the data. Course outlines were reviewed in full and themes of information were coded deductively, relative to predetermined analysis categories. Analysis categories used for the thematic analysis were determined using Kolb's experiential learning cycle, In particular the following learning modes were used as the main categories of analysis: concrete experience, reflective observation, abstract conceptualization, and active experimentation. Each course outline was coded individually and coded themes within each category of analysis were categorized inductively to determine subthemes. Data were then charted in flow diagrams to illustrate a representation of the coded themes and subthemes of data reflected in the course outlines reviewed. In this phase of the research one researcher was assigned to review all program outlines in full and conduct the preliminary coding of information included. The categorization of themes and inductive categorization of coded meaning units was then conducted by a group of three researchers in order to assure trustworthiness in the analysis process.

\section{Results}

\section{Part I: Web-based Analysis}

The web-based search yielded a total of 369 internship programs of which 152 were from colleges and 217 were from universities. Of the 44 institutions examined, Ontario colleges represented $41.2 \%$ of total internship programs recorded; Ontario universities accounted for $58.5 \%$ of total internship programs recorded. The results were organized into the following categories: program characteristics, internship prerequisites, and internship conditions.

\section{Program Characteristics}

Field of study. Internship programs were listed as belonging to one of the following fields of study: professional faculties/trades, life sciences, or social sciences/humanities. Professional faculties/trades accounted for $54.7 \%$ of the sample $(n=202)$. Examples of professional faculties/trades included business, engineering, kinesiology, applied and professional studies, information studies, and music. Internships in the life sciences, which constituted $18.9 \%(n=70)$ of the sample, included disciplines such as biology, earth science, health science, forensic science, astronomy, physics, actuarial science, and computer science. Lastly, the social sciences/humanities category accounted for $9.2 \%$ ( $n$ $=34$ ) of internship programs in fields of study such as geography, social science, social work, political studies, international studies, anthropology, global studies, medieval studies, classical studies, film studies, and visual arts. The remaining $17.1 \%(n=63)$ of the 
internship programs did not explicitly specify the field of study in which the internship was being offered. This information is highlighted in Figure 1.

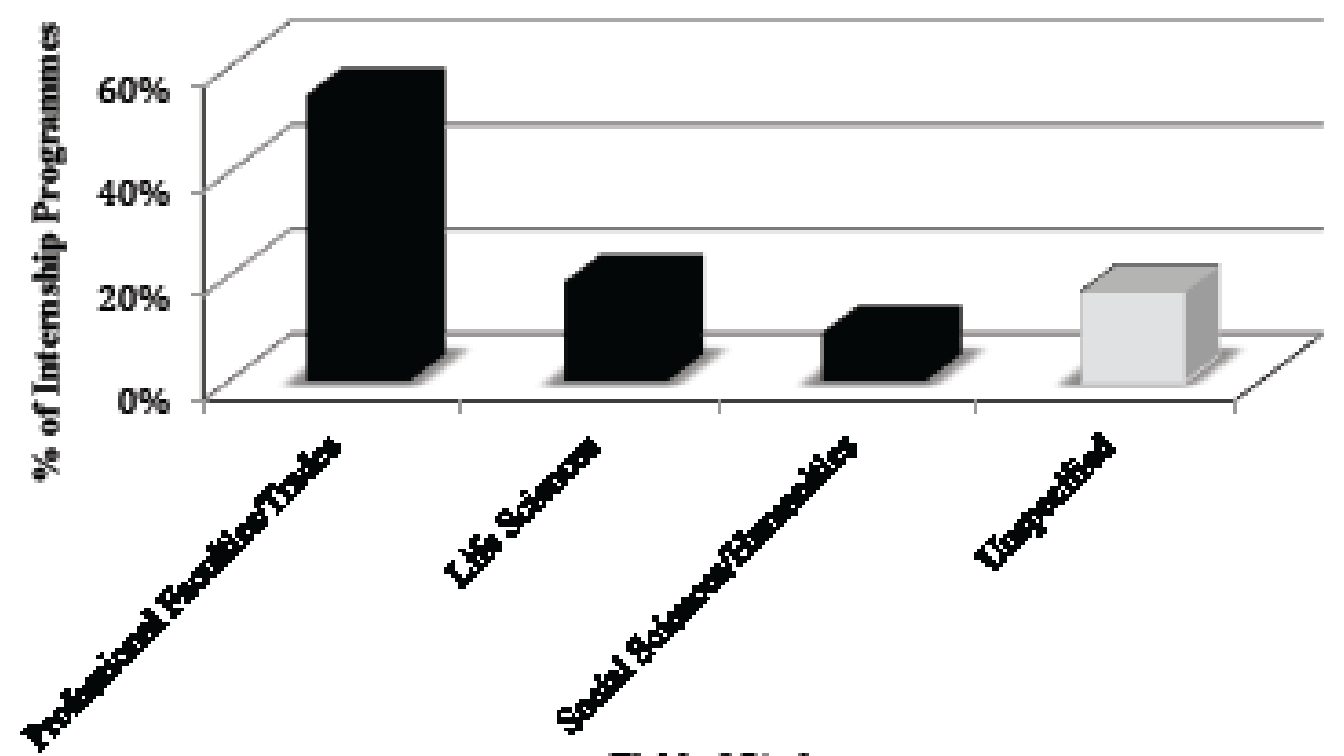

Field of Study

Figure 1. Internship field of study.

Internship characteristics. Of the 369 internship programs, $45.0 \%(n=166)$ specified they were offered as course credit; $7.6 \%(n=28)$ were offered as a non-course credit. The remaining 47.4\% $(n=175)$ did not specify. Among other programs $13.6 \%(n$ $=50)$ were optional for students and $13.8 \%(n=51)$ were required for graduation. The remaining $72.6 \%(n=268)$ did not specify.

From an administrative standpoint, student enrolment in a specific degree program was a criterion for $57.5 \%(n=212)$ of internship programs and $17.1 \%(n=63)$ of programs required the student be enrolled in academic courses throughout their participation in the internship. Further, $12.5 \%(n=46)$ required the students to organize and set up their internship experience themselves.

Finally, of the internships identified in the web analysis, $24.4 \%(n=90)$ specified that the program was available in a regional location close to the institution, and 8.7\% ( $n=$ 32) specified that the internship could be completed at another site within Canada or at an international location (e.g., USA, China, Taiwan, Australia, Turkey, England, Scotland, Bangladesh, Kenya, New Zealand, Mexico, Brazil, or Greece). The remaining 66.9\% ( $n=$ 247) did not specify the location of the internship.

Internship prerequisites. A variety of prerequisites were specified by the internship programs examined, including academic prerequisites, citizenship prerequisites, and fees.

Academic prerequisites. To be eligible to participate in an internship program, $31.2 \%(n=115)$ of internships required the student to complete prerequisite or corequisite courses prior to enrolment. In addition, 3.5\% $(n=13)$ of the programs required the student achieve a specified grade percentage in those prerequisite or corequisite courses. Moreover, $4.6 \%(n=17)$ of programs specified that the student(s) be on the honour roll to 
be eligible for participation in the internship, while $18.7 \%(n=69)$ specified a minimum grade point average (GPA) for participation. Lastly, being a full-time student was specified as a criterion by $21.7 \%(n=80)$ of internship programs. The remaining $20.3 \%(n=$ 75) of the programs did not specify a particular course of GPA prerequisite.

Of the total number of internship programs documented, 10.6\% $(n=39)$ required the applying student(s) be first-year students; $18.4 \%(n=68)$ required the student(s) be second-year students; 30.9\% $(n=114)$ required the student(s) be third-year students; and $21.4 \%(n=79)$ required the student(s) be fourth-year students. The remaining $18.7 \%(n=$ 69) programs did not specify a particular year of study for participation.

Citizenship prerequisites. In addition, data regarding the citizenship and required experiences of the student were recorded. Of those internship programs that specified citizenship requirements $(n=246), 33.3 \%(n=123)$ of internship programs were available to Canadian citizens and $33.3 \%(n=123)$ of internship programs were open to international students. The remaining 33.3\% $(n=123)$ did not specify citizen prerequisites.

Fees. Data revealed that $34.1 \%(n=126)$ of internships required the student pay fees to participate in the programs. Of those internship programs that required a fee, $28.6 \%$ required the student pay $\$ 1-\$ 500(n=36) ; 9.5 \%$ of programs required the student pay $\$ 501-\$ 1,000(n=12) ; 10.3 \%$ required the student pay $\$ 1,001-\$ 5,000(n=13) ; 41.3 \%$ required the student pay $\$ 5,001-\$ 10,000(n=52) ; 10.3 \%$ of programs did not specify a dollar amount $(n=13)$. In the majority of cases, it was not specified whether or not the fee was an ancillary fee-a fee charged in addition to student tuition-or if the fee was included in the tuition.

Internship conditions. Various conditions were specified by the internship programs examined, including both conditions for compensation and requirements of the internship itself.

Compensation. One noteworthy characteristic of internship programs was the range of compensation offered to students for their participation. From the total number of internships recorded, $14.4 \%(n=53)$ specified they were paid internships; $24.4 \%(n=$ $75)$ specified they were unpaid internships; $61.2 \%(n=226)$ provided no details concerning compensation. Of the paid internships, 7.5\% $(n=4)$ offered compensation ranging from $\$ 0-\$ 20,000 ; 13.2 \%(n=7)$ offered compensation ranging from $\$ 20,001-\$ 40,000$; $13.2 \%(n=7)$ offered compensation ranging from $\$ 40,001-\$ 60,000 ; 66.1 \%(n=35)$ did not specify an amount for compensation. In general, higher levels of compensation $(>\$ 20,000)$ were seen in internship program descriptions from professional faculties and trades, such as business and engineering and often required full-time commitment as well as a period of time away from academic studies, such as a professional experience year.

Internship requirements. Internship programs commonly outlined the number of hours required of the student to complete the internship. When considering internship program requirements in terms of total hours $(n=78)$, 11.5\% of internship programs required $1-50$ hours $(n=9) ; 20.5 \%$ of internship programs required $51-100$ hours $(n=16)$; $35.9 \%$ of internship programs required $101-300$ hours $(n=28) ; 26.9 \%$ of internship programs required $301-600$ hours $(n=21)$; and $5.1 \%$ of internship programs required $601-1,000$ hours $(n=4)$. When considering internship program requirements in terms of hours to be completed per week $(n=17), 47.1 \%$ required $1-10$ hours per week $(n=8)$; $11.8 \%$ of required $11-20$ hours per week $(n=2)$; $\%$ of internships required $21-30$ hours 
per week $(n=0)$; and $41.2 \%$ required $31-40$ hours per week $(n=7)$. This information is outlined in Figure 2. The remaining $74.3 \%(n=274)$ did not specify the internship hours.

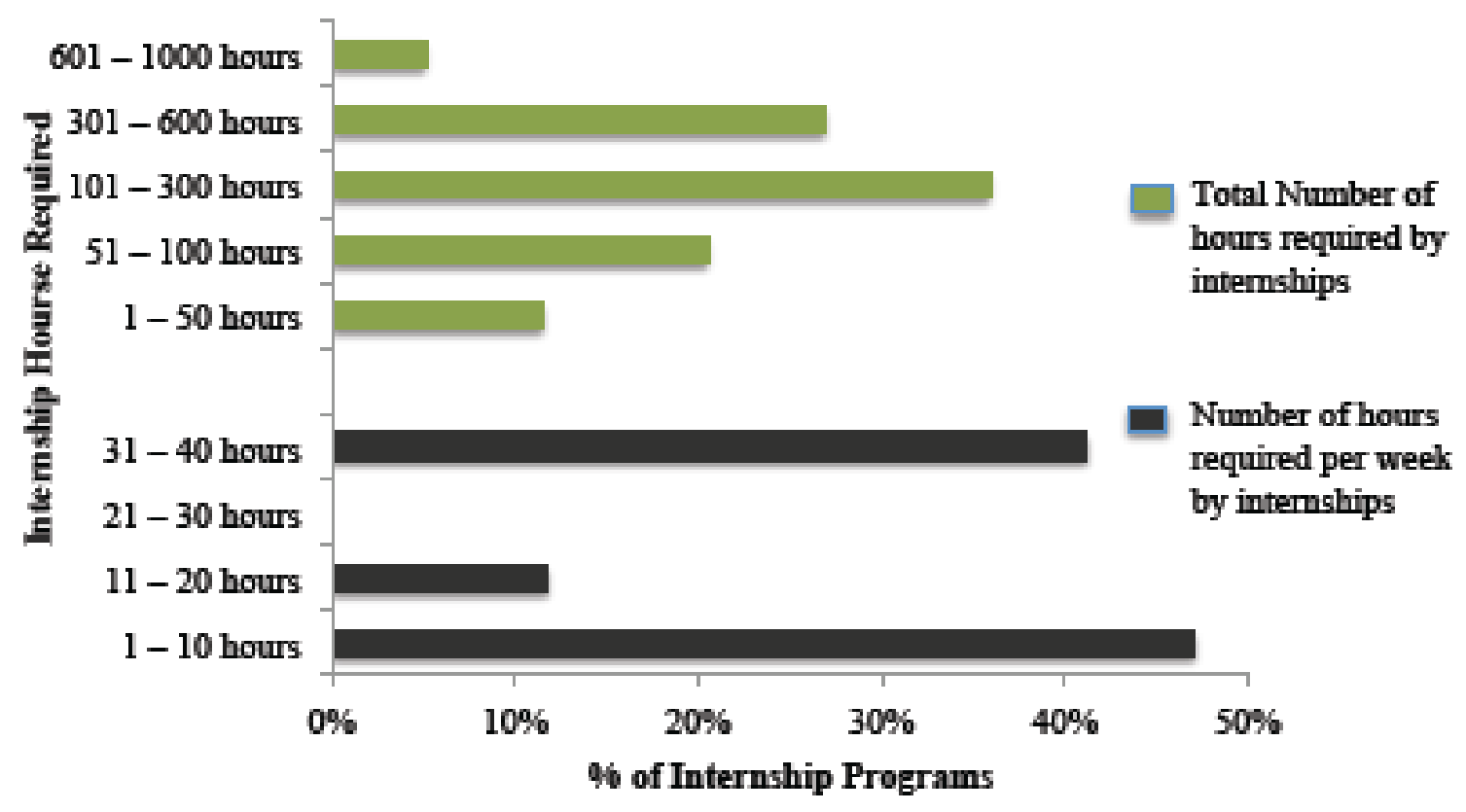

Figure 2. Number of internship hours required

Of the programs that specified the length of the internship, $37.6 \%$ required $1-3$ months ( $n=70) ; 24.7 \%$ required $3-6$ months $(n=46) ; 10.2 \%$ required $6-9$ months $(n=19)$; $10.2 \%$ required $9-12$ months $(n=19) ; 16.1 \%$ required $12-16$ months $(n=30)$; and $1.1 \%$ required 16 months+ $(n=2)$. The remaining $62.1 \%(n=229)$ did not specify the length of the internship.

\section{Summary of Part I}

The web-based analysis of the internship programs identified the diversity within postsecondary institutions. In most cases, a specific definition of the internship program was not articulated; instead, the meaning had to be inferred from descriptions of the internship program prerequisites and conditions. The most frequently cited internship conditions gleaned from the web analyses included descriptors of the internship, such as compensation, number of hours to be completed, number of months to be completed, and prerequisites. Together, these descriptors contribute to the emerging finding that postsecondary internship programs are diverse and that there is significant variation in the stated conditions of the internship itself, as well as the stated requirements of the student intern.

\section{Part II - Internship Program Outlines}

Program outlines were collected for 77 internship programs. The analysis of the program outlines included identification of the intended learning outcomes of each internship program, the educational components, and best practices of each program. This con- 
tent was then analyzed using Kolb's (1984) experiential learning theory. The results are organized according to each of Kolb's four experiential learning modes: concrete experience, reflective observation, abstract conceptualization, and active experimentation.

Concrete experience. Concrete experience is the hands-on experience from participating in a new situation. This mode, according to Kolb et al. (2001), is about grasping experience and perceiving "new information through experiencing the concrete, tangible, felt qualities of the world, relying on our senses and immersing ourselves in concrete reality" (p. 3). The concrete experience mode of Kolb's experiential learning theory was well represented in the program outlines collected. Tangible elements of the internship were outlined including, the practical hours completed by the student, common internship tasks and responsibilities, and components of the internship that make it a diverse experience. The predominance of the concrete experience mode in the outlines is important to highlight because it illustrates an emphasis on the logistic components of the experience. It suggests a common understanding of the importance of including concrete details of a student's hands-on learning. However, consistent with previous findings from the first phase of the results, there is substantial variance in these details. The identified themes, subthemes, and examples of the concrete experience mode are illustrated in Figure 3.

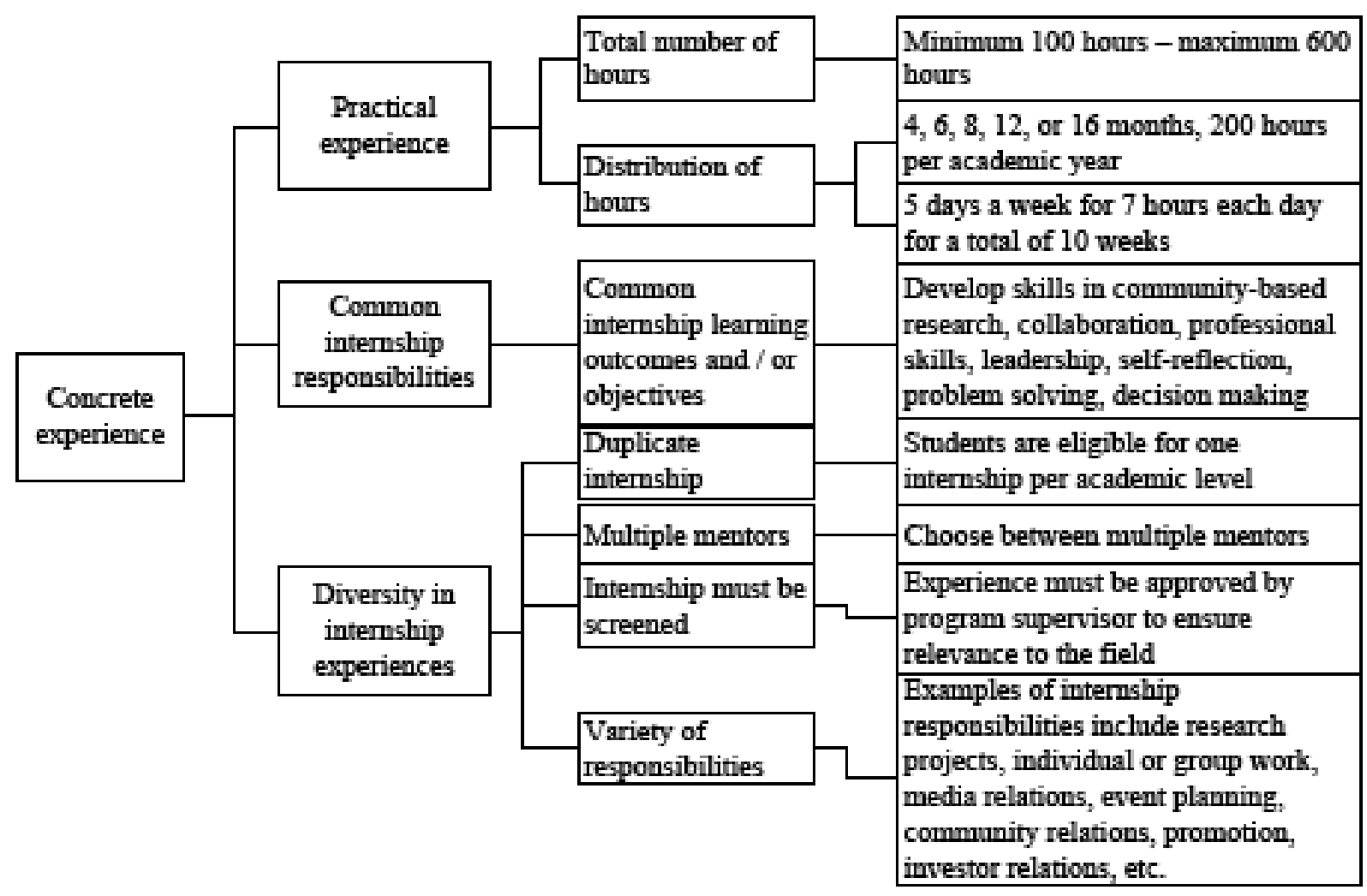

Figure 3. Concrete experience: educational conditions of Ontario colleges and university internship programs. 
Reflective observation. Reflective observation is process of taking in an experience and reflecting back on it. It includes both the act of reflecting on one's own hands-on experiences and the experience of watching others (Kolb et al., 2001). Examples from the course outlines with respect to the reflective observation mode include mentor shadowing, which requires pairing an intern with a specific team or area of his or her internship organization for supervision; training and orientation, which consists of activities, workshops, or training that is completed prior to or throughout the student's internship; reflective writing, such as assignments, final reports, midterm journals, or blogs; and reflective discussion, including final presentations, ongoing feedback meetings, exit interviews, or class/tutorial discussions. The identified themes, subthemes, and examples of the reflective observation mode are illustrated in Figure 4.

Overall, the reflective observation mode was very well represented in the program outlines collected. Opportunities for training and orientation, reflective writing assignments, and reflective discussion represented a variety of means through which students could demonstrate abilities to reflect on their practical experiences. Reflective writing and reflective discussion were commonly used and support the reflective observation mode, which is important to highlight because they exemplify the integration of academic responsibilities within practical experience. Participation in tutorial discussions, feedback meetings, and final presentations were commonly cited oral assessments. Consistent with the results from Part I, however, is the finding of significant variation in the ways in which reflective observation is demonstrated. All of these findings contribute to an emerging trend that internships differ in their representation, opportunities for, and evaluation of the reflective observation mode.

Abstract conceptualization. Abstract conceptualization refers to the ability to take experience and relate it to overarching theory or to create new ideas from it. According to Kolb et al. (2001), this mode is represented by individuals who perceive, grasp, or take hold of new information through symbolic representation or abstract conceptualization-thinking about, analyzing, or systematically planning, rather than using sensation as a guide (p. 3). One of the themes within the abstract conceptualization mode was the intersection between the internship and the class work. This intersection was represented by three different models, including an integrated model (i.e., internship occurs concurrently with academic courses), a distinct model (i.e., internship occurs separately from academic courses), and a mixed model (i.e., internship occurs at the same time as courses but remains independent of course work). Other themes that emerged under the abstract conceptualization phase included common learning outcomes and/or objectives, such as generalizable professional skill development and career-specific skill development; connection with previous courses and/or learning, including prerequisite courses and curricular knowledge; and idea generation, such as the development of recommendations for future practice in the field. The identified themes, subthemes, and examples of the abstract conceptualization mode are illustrated in Figure 5.

Overall, the cognitive dimension of Kolb's experiential learning theory-abstract conceptualization-was the least well-represented dimension in the program outlines. Examples of the class work intersecting with the practical experience of an internship, the students' application of general and career-specific skills, and the students' connection with previous curricular learning, and demonstrations of idea generation were noticeably absent from the outlines. 


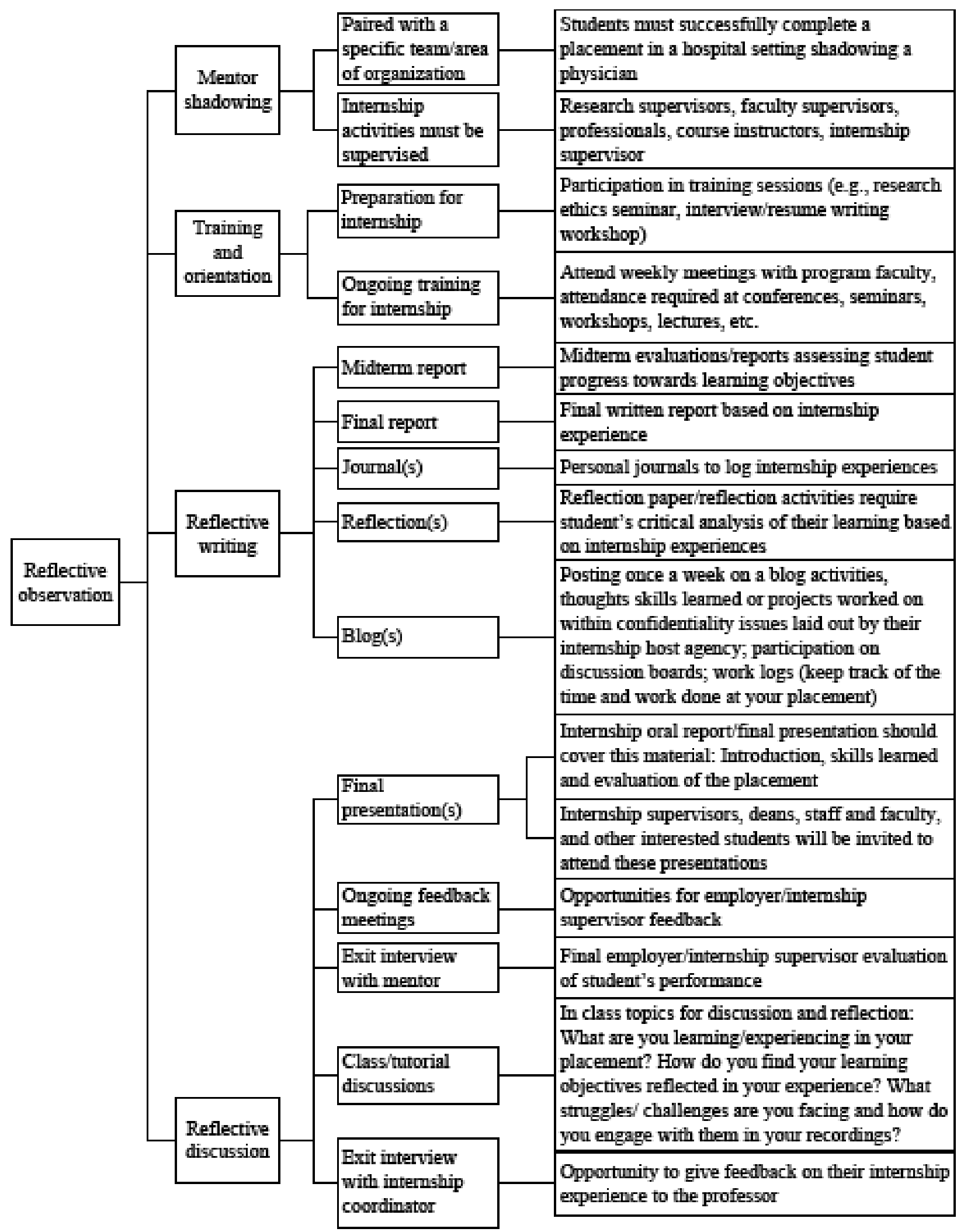

Figure 4. Reflective observation: educational conditions of Ontario colleges and university internship programs. 


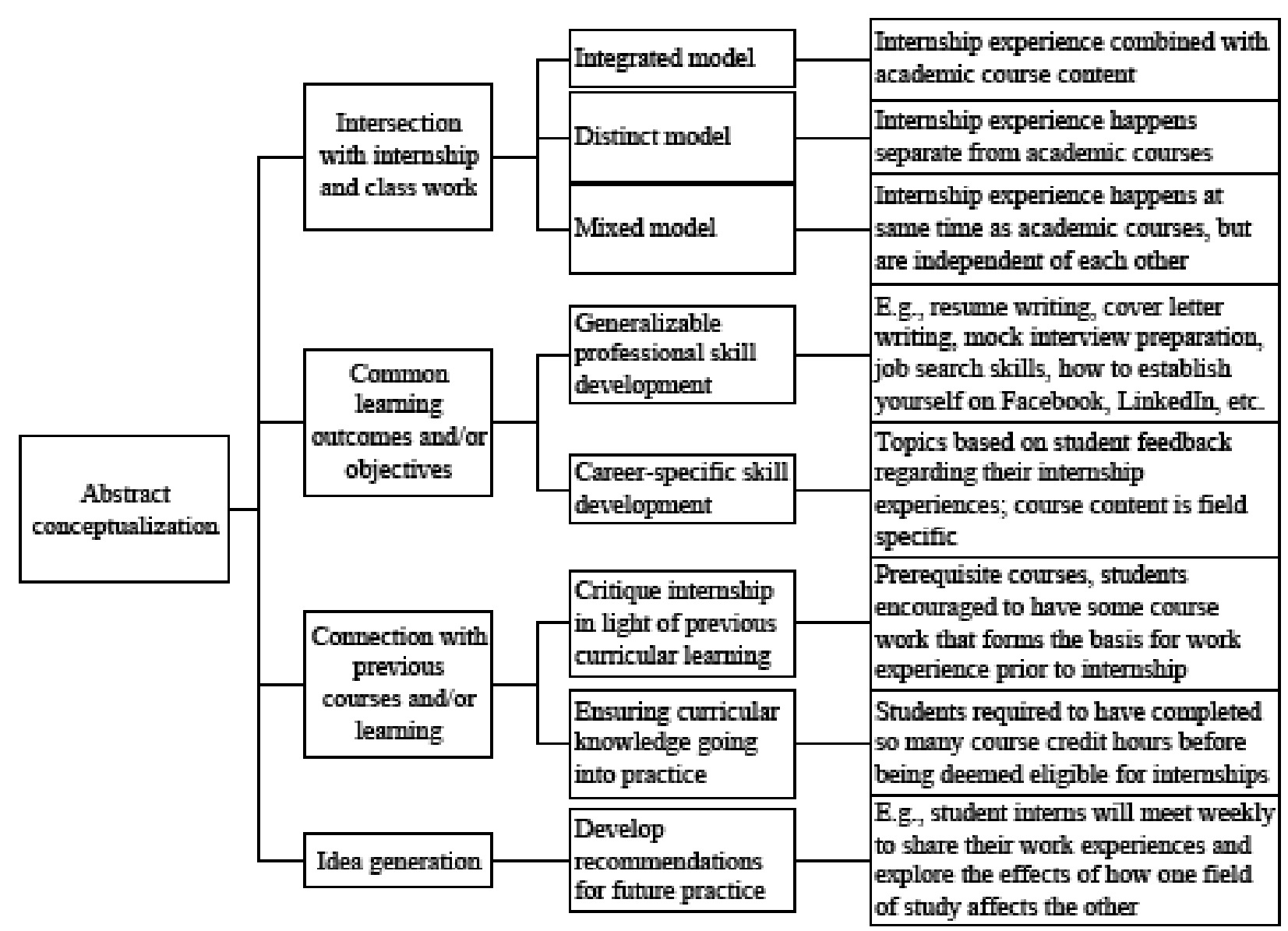

Figure 5. Abstract concepturalization: educational conditions of Ontario colleges and university internship programs.

Active experimentation. Active experimentation involves applying to practice what has been learned and conceptualized in theory (Kolb et al., 2001. Examples of the active experimentation phase of Kolb's theory were represented through the students' ability to apply new ideas through the generation of research related to the internship environment or adaptation of innovative practices to emerging needs of the field; apply curricular learning to their internship, including the development and/or implementation of a project (e.g., planning a special event for clients); and apply professional skills throughout the internship, such as leadership. The identified themes, subthemes, and examples of the active experimentation mode are illustrated in Figure 6.

Overall, the active experimentation mode of Kolb's experiential learning theory was not clearly identifiable in most outlines. Opportunities to apply new ideas through the generation of research were available primarily to those students who engaged in research-based internships. This suggests that applying new ideas, as evidence to support the active experimentation mode within Kolb's experiential learning theory, was specific to research-based internship opportunities and was not well represented in non-researchbased internships. In addition, connections between students' application of curricular learning and their internship were not made explicit. 


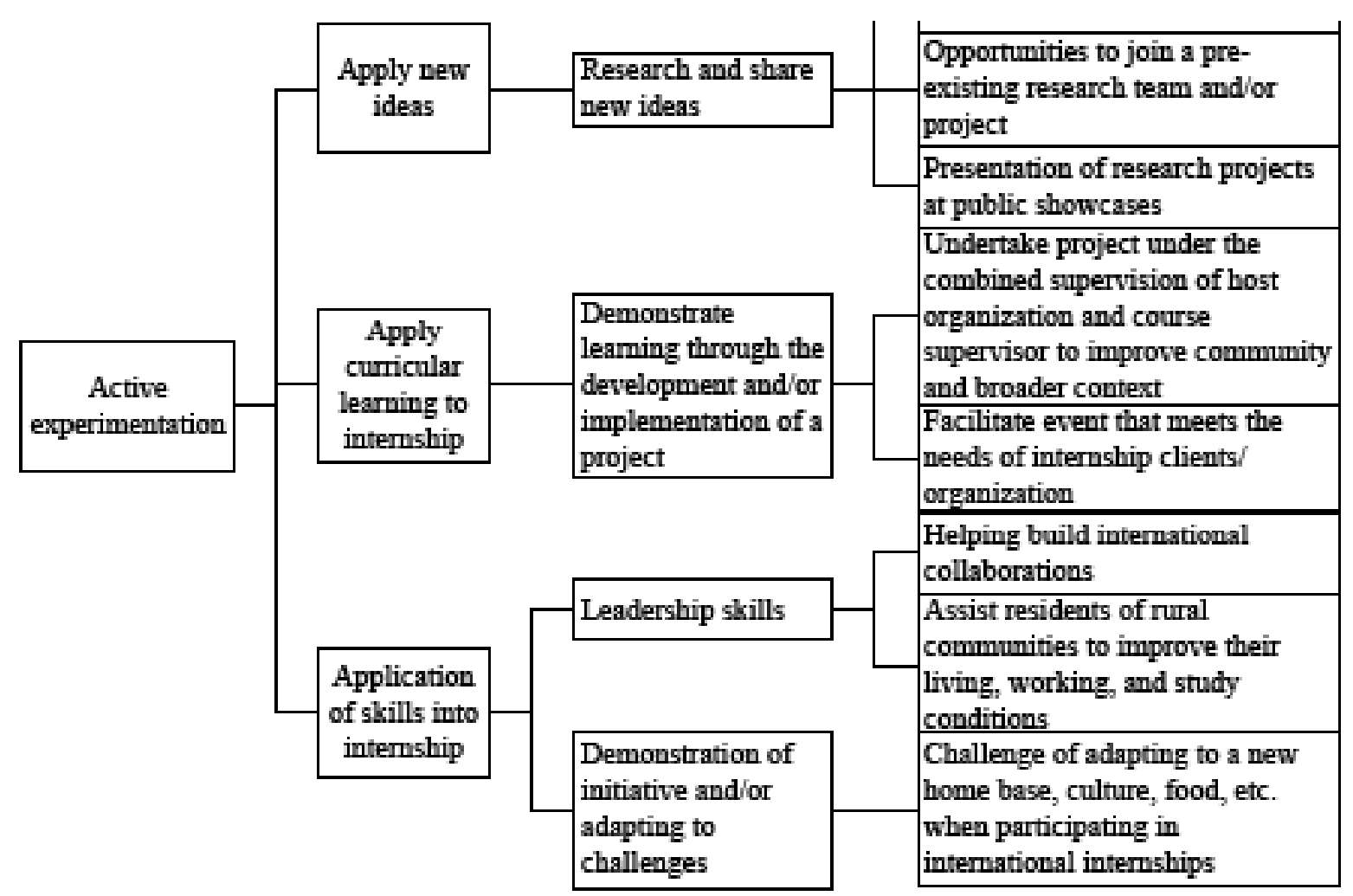

Figure 6. Active experiementation: educational conditions of Ontario colleges and university internship programs.

\section{Discussion}

The purpose of this study was to examine the internship opportunities facilitated by first-entry postsecondary institutions in Ontario with a focus on the characteristics of and conditions associated with these experiences. Further, we sought to examine the extent to which the various internships were consistent with the requirements of effective experiential learning. To assess whether internships are designed in accordance with the criteria by which learning through experience occurs most effectively, the data analysis was grounded in Kolb's (1984) experiential learning theory.

Findings from Part I of data analysis indicated there is significant variation with regard to the characteristics and conditions of Ontario postsecondary internship programs. There is no consistency across programs in terms of prerequisites, the granting of credit/ no-credit, fees, whether the internship was part of or separate from an academic course, number of hours involved, whether or not compensation was provided, or student roles and responsibilities. It is our supposition, however, that this variability is irrelevant as long as the internship experiences are educational. It is quite possible, given the range of college and university programs and their corresponding variations in learning outcomes, curricula, and degree requirements, that differences are warranted. What is common across all internship programs however, is the need for these experiences to be educational. One could argue that, without added educational value, there is no place for internships within colleges and universities. 
From a broad perspective, internships should emphasize educational experiences that develop and advance knowledge delivered in the classroom (Sides \& Mrvica, 2007). To achieve this, it is necessary for postsecondary institutions to develop and implement a theoretical component to internship experiences (Alpert et al., 2009), one that requires the students to reflect and think critically about their experiences in the workplace (Sides \& Mrvica, 2007). While the suggestions posed by Sides and Mrvica (2007) are useful for the design and delivery of internships, they represent only two modes of learning in Kolb's (1984) theory: concrete experience and reflective observation. Building on the criteria outlined by Alpert et al., and Sides and Mrvica, Kolb's approach adds the need for abstract conceptualization and active experimentation, which encourages learners to make critical connections between the internship and theoretical coursework, to connect previous courses to current learning experiences, and to develop and implement new ideas into practice.

From the perspective of Moore (2010), the greatest limitation of higher education experiential activities, including internship opportunities, is an overemphasis on the practical level of the experience and a lack of emphasis on the connection between experience and curricular learning. This proposition was supported by the findings of the present study, which found that conditions for concrete experience and reflective observation were well incorporated into the program outlines; however, the abstract conceptualization and active experimentation modes were largely absent. As all four learning modes must be addressed for learning to be most effective, the lack of representation of at least two modes highlights important areas for further attention and research. It is fully recognized that even though these learning modes were not addressed in the course outlines, they may have been attended to in the practice of the internships themselves. Further research should look more specifically at the pedagogical practices of Ontario internship programs in order to assure the conditions for optimal learning are currently being met and, if not, to recognize potential areas and measures for improvement.

With respect to abstract conceptualization, the findings may be interpreted as suggesting that this mode of experience is ineffectively embedded within internship programs. This point is reflected in the lack of purposive conditions and lack of explicit descriptions on ways in which students can generate intersections between practical experience and theory. Again further research is required in this area. In addition, in order to advance developments of this mode, further initiatives are needed to encourage students to integrate knowledge and skills developed in the internship with relevant theory and coursework, including previous curricular learning.

The program outlines also failed, for the most part, to incorporate the active experimentation mode of Kolb's experiential learning theory. Further research is required on the pedagogical practice of experimentation within students' internship experience. Looking solely at the course outlines, it is suggested that students are typically not provided with the opportunity to apply new ideas generated from the intersection of theory and experience back to practice within the internship. The exception to this was in research-related internships that integrated the application of new ideas and skills within the experience. These data led us to question the importance placed by internship programs on the transfer of learning from an academic context to the internship context, and vice versa. Again, this is a question that requires further investigation. 
O'Neill (2010) purports that to ensure an experience is educational, it must be a collaborative effort and include discussions amongst students, academic faculty, course coordinators, and industry professionals regarding internship goals. Using this approach, it is proposed that postsecondary institutions be responsible for creating the educational conditions for the internship using empirical learning theory, such as Kolb's (1984) theoretical framework. This would include but is not limited to outlining learning objectives and outcomes, creating opportunities for critical reflection, encouraging the generation and implementation of new ideas, and establishing activities that promote intersections between the internship and coursework. With this predetermined academic framework, the role of the industry professionals would be to consult with the course coordinator and student to establish challenging day-to-day tasks, which allow the student to fulfill these goals. Further, the industry professional would be required to monitor these activities and provide feedback to the student throughout his or her engagement in the internship.

Finally, the main responsibilities of the student would be to maintain communication with the internship mentor and academic program leader, complete related coursework, and meet the expectations of the internship experience (O'Neill, 2010). O'Neill (2010) suggests progress meetings involving all three parties (i.e., student, institution, and employer) take place throughout the internship to ensure that academic goals are being met and the working relationship remains collaborative. We further suggest that learning plans created in partnership between the student and workplace supervisor should include activities in alignment with each mode of learning. A comprehensive outline of the roles and responsibilities of each stakeholder would also mitigate some of the criticisms of internships identified by Hanson (1984), such as lack of proper planning and insufficient supervision.

\section{Limitations}

This study is limited by its exploratory nature and its focus on document analysis. The findings derived from the analysis of program webpages and outlines are limited to the information provided online, and prioritized and included in the outlines provided by the institution. It is recognized that some internship programs may involve more educational tasks for students beyond those that were detailed online or in the program outlines. The lack of response from internship program coordinators and the lack of internship course outlines is a further limitation. The research is also limited by the exclusive focus on postsecondary experiences entitled "internships." Due to this distinct focus, all other work-integrated learning opportunities offered through postsecondary institutions, including practicums, apprenticeships, field placements, cooperative education, etc., were not examined.

\section{Future Directions}

This exploratory study sheds light on a number of areas for future research. Building upon the document analysis conducted, future research should examine the conceptual and operational perspectives of internship course coordinators and the alignment of these practices with empirical learning theory. Other questions related to the current research include the following:

- What are the intended learning outcomes of postsecondary internship programs?

- What is the connection between the internship programs and the broader mission and curricula of the academic programs? 
- Do internship programs reflect an orientation to close the theory-practice gap in higher education?

- What role may internships play in integrating theory and practice, and attending to varying learning styles in postsecondary institutions?

- What barriers exist that may limit internship programs from capitalizing on their experiential learning potential?

- Do program leaders have a clear understanding of their educational roles in the design and delivery of the internship programs?

- And, in what ways may feedback, learning assessment, and partnerships between the internship employer, placement coordinator, and student enhance the educational quality of the internship experience?

\section{Conclusion}

In summary, the learning activities included in the internship course outlines examined did not address the four learning modes of experiential learning theory required to ensure an optimal learning experience for all students. Regardless of the wide discrepancies in conditions or prerequisites between programs, the quality of an internship experience should be determined by the educational enrichment the experience provides for the learner. The findings suggest that to enhance the educational value of internships, postsecondary programs need to move beyond the current emphasis on the provision of practical experiences to strengthening components of reflection, linking coursework and practical experience, and providing opportunities for students to implement creative ideas into practice. With increased attention to theoretically informed educational conditions, the design and delivery of internships would allow every student an opportunity to gain the most important asset of all: a high-quality educational experience.

\section{References}

Alpert, F., Heaney, J., \& Kuhn, K. L. (2009). Internships in marketing: Goals, structures and assessment-Student, company and academic perspectives. Australasian Marketing Journal, 17(1), 36-45.

Baird, B. N. (1996). The internship, practicum, and field placement handbook: A guide for the helping professions. Englewood Cliffs, NJ: Prentice-Hall.

Beard, C., \& Wilson, J. P. (2013). Experiential learning: A handbook for education, training and coaching ( ${ }^{\text {rd }}$ Ed.). Philadelphia, PA: Kogan Page.

Billett, S. (1996). Towards a model of workplace learning: the learning curriculum. Studies in Continuing Education, 18(1), 43-58.

Billett, S. (2002). Workplace pedagogic practices: co-participation and learning. British Journal of Educational Studies, 5o(4), 457-481.

Billett, S. (2011). Curriculum and pedagogical basis for effectively integrating practice-based experiences. Sydney: Australian Learning and Teaching Council.

Bontis, N. (1999). Managing organizational knowledge by diagnosing intellectual capital: Framing and advancing the state of the field. International Journal of Technology Management, 18, 433-462. 
Brookfield, S. (1990). The skillful teacher. San Francisco, CA: Jossey-Bass.

Cantor, J. A. (1997). Experiential learning in higher education: linking classroom and community. The George Washington University, Graduate School of Education and Human Development. Washington, DC.

Ciofalo, A. (1992). Internships: Perspectives on experiential learning. A guide to internship management for educators and professionals. Melbourne, FL: Krieger Publishing Co.

Coco, M. (2000). Internships: A try before you buy arrangement. SAM Advanced Management Journal, 65(2), 41.

Dewey, J. (1938). Experience and education. New York, NY: Collier Macmillan.

Divine, R. L., Linrud, J. K., Miller, R. H., \& Wilson, J. H. (2007). Required internship programs in marketing: Benefits, challenges, and determinants of fit. Marketing Education Review, 17, 45-52.

Dunn, M. E. (2015). Reclaiming opportunities for effective teaching: An institutional ethnographic study of community college course outlines. Lanham, MD: Lexington Books.

Evans, N. J., Forney, D. S., Guido, F. M., Patton, L. D., \& Renn, K. A. (2010). Student development in college: Theory, research, and practice (2nd Ed.). San Francisco, CA: Jossey-Bass.

Gault, J., Leach, E., \& Duey, M. (2010). Effects of business internships on job marketability: The employers' perspective. Education + Training, 52(1), 76-88.

Guile, D., \& Griffiths, T. (2001). Learning through work experience. Journal of education and work, 14(1), 113-131.

Hanson, J. (1984). Internships and the individual: Suggestions for implementing (or improving) and internship program. Communication Education, 33(1), 53-61.

Hergert, M. (2009). Student perceptions of the value of internships in business education. American Journal of Business Education, 2(8), 9-14.

Hicks, M., Weingarten, H. P., Jonker, L., \& Liu, S. (2013). The diversity of Ontario's colleges: a data set to inform the differentiation discussion. Toronto: Higher Education Quality Council of Ontario. Retrieved October 28, 2016 from http://www.heqco.ca/ SiteCollectionDocuments.

Hopkins, J. R. (1999). Studying abroad as a form of experiential education. Liberal Education, 85(3), 36-41.

Jarvis, P. (1995). Adult and continuing education. (2nd ed.). London, UK: Routledge.

Jowdy, E., McDonald, M., \& Spence, K. (2004). An integral approach to sport management internships. European Sport Management Quarterly, 4(4), $215 \mathrm{v} 233$.

Keating, S. (2006). Learning in the workplace: a literature review. Victoria University, Postcompulsory Education Centre. Retrieved June 15, 2015 from http://tls.vu.edu.au/ PEC/PEC_docs/PEC\%20LIW\%2oliterature\%2oreview\%2ofinal.pdf.

Kelly, C. (1997). David Kolb, the theory of experiential learning and ESL. The Internet TESL Journal, 3(9), 1-5. 
Kemp, J., Morrison, G., \& Ross, S. (1996). Designing effective instruction. Upper Saddle River, NJ: Prentice-Hall.

Knemeyer, A. M., \& Murphy, P. R. (2002). Logistics internships: Employer and student perspectives. International Journal of Physical Distribution \& Logistics Management, 32(2), 135-152.

Kolb, D. A. (1981). Learning styles and disciplinary differences. In A. W. Chickering (ed.), The modern American college: Responding to the new realities of diverse students and a changing society (pp. 232-255). San Francisco, CA: Jossey-Bass.

Kolb, D. A. (1984). Experiential learning: Experience as the source of learning and development. Englewood Cliffs, NJ: Prentice Hall.

Kolb, D. A., Boyatzis, R. E., \& Mainemelis, C. (2001). Experiential learning theory: Previous research and new directions. In R. J. Sternberg and L. F. Zhang (eds.), Perspectives on cognitive learning and thinking styles (pp.227-247). Mahwah, NJ: Lawrence Erlbaum.

Kolb, A. Y., \& Kolb, D. A. (2005). Learning styles and learning spaces: Enhancing experiential learning in higher education. Academy of Management, Learning \& Education, 4, 193-212.

Krippendorff, K. (2012). Content analysis: An introduction to its methodology. Thousand Oaks, CA: Sage.

Kuh, G. D. (2008). High-impact educational practices: What they are, who has access to them, and why they matter. Washington, DC: Association of American Colleges and Universities.

Lave, J., \& Wenger, E. (1991). Situated learning: legitimate peripheral participation. New York, NY: Cambridge University Press.

Lempert, D. H.(1996). Escape from the ivory tower: student adventures in democratic experiential education. San Francisco, CA: Jossey-Bass.

Lewin, K. (1951). Field theory in social science: selected theoretical papers. New York, NY: Harper \& Row.

McKeachie, W. J. (1994). Teaching tips. Lexington: D.C. Heath and Company.

McKnight, Z. (2013). Young, unpaid workers face thin protections under Ontario law. Toronto Star. Retrieved October 28, 2016 from http://www.thestar.com/news/ gta/2013/10/17/young_unpaid_workers_face_thin_protections_under_ontario_law. html.

McMillan, S. J. (2000). The microscope and the moving target: The challenge of applying content analysis to the World Wide Web. Journalism \& Mass Communication, 77, 80-98.

Meyer, K. A., \& Wilson, J. L. (2010). The "virtual face" of planning: How to use higher education web sites to access competitive advantage. Planning for Higher Education, $38(2), 11-21$. 
Moore, D. T. (2010). Forms and issues in experiential education. In D. M. Qualters (ed.), Experiential education: Making the most of learning outside the classroom (pp. 3-14). San Francisco, CA: Jossey-Bass.

Moorman, A. M. (2004). Legal issues and the supervised internship relationship: Who is responsible for what? Journal of Physical Education, Recreation \& Dance, 75(2), 19-24.

Neuendorf, K. A. (2002). The content analysis guidebook. Thousand Oaks: CA. Sage.

O’Neill, N. (2010). Internships as a high-impact practice: Some reflections on quality. Peer Review, 12(4), 4-8.

Paris, A. J., \& Adams, H. G. (1994). Yourinternship is as good as you makeit: A practical guide to student internships. Notre Dame, IN: National Consortium for Graduate Degrees for Minorities in Engineering, Inc. Retrieved from http://eric.ed.gov/?id=ED379974.

Piaget, J. (1971). Psychology and epistemology. Harmondsworth, UK: Penguin.

Priest, S., \& Gass, M. A. (1997). Effective leadership in adventure programming. Champaign, IL: Human Kinetics.

Rogers, A. (1996). Teaching Adults (2nd Ed.). Buckingham: Open University Press.

Rothman, M. (2007). Lessons learned: Advice to employers from interns. Journal of Education for Business, 82, 140-144.

Sattler, P. (2011). Work-integrated learning in Ontario's postsecondary sector. Toronto, ON: Higher Education Quality Council of Ontario.

Sattler, P., \& Peters, J. (2013). Work-integrated learning in Ontario's postsecondary sector: The experience of Ontario graduates. Toronto, ON: Higher Education Quality Council of Ontario.

Seaman, J. (2008). Experience, reflect, critique: The end of the "learning cycles" era. Journal of Experiential Education, 31(1), 3-18.

Schmutte, J. (1986). Accounting internships: The state of the art. Journal of Accounting Education, 4(1), 227-236.

Sides, C. H., \& Mrvica, A. (2007). Internships: Theory and practice. Amityville, NY: Baywood Publishing.

Swan, A. \& Carr, L. (2008). Institutions, their repositories and the web. Serials Review, 34, 31-35.

Thiel, G. R., \& Hartley, N. T. (1997). Cooperative education: A natural synergy between business and academia. SAM Advanced Management Journal, 62, 19-24.

Tovey, J. (2001). Building connections between industry and university: Implementing an internship program at a regional university. Technical Communication Quarterly, 10(2), 225-239.

Venkateswarly, T. (2002). Economic development: Survey of course outlines in North American universities. American Economist, 46, 71-77.

Vince, R. (1998). Behind and beyond Kolb's learning cycle. Journal of Management Education, 22(3), 304-319. 
Weingarten, H. P., Hicks, M., Jonker, L., \& Liu, S. (2013). The diversity of Ontario's universities: A data set to inform the differentiation discussion. Toronto: Higher Education Quality Council of Ontario. Retrieved Octover 28, 2016 from http://www. heqco.ca/SiteCollectionDocuments/HEQCO\%20Diversity_ENG.pdf.

Weare, C. (2000). Content analysis of the World Wide Web: Opportunities and challenges. Social Science Computer Review, 18, 272-292.

\section{Contact Information}

Ashley Stirling

Faculty of Kinesiology and Physical Education

University of Toronto

ashley.stirling@utoronto.ca

Ashley Stirling is an assistant professor, teaching stream, and director of experiential education in the Faculty of Kinesiology and Physical Education, University of Toronto. She has expertise in the areas of work-integrated learning, experiential learning, curriculum evaluation, and training resource development. She is the Faculty's specialist in experiential education and is responsible for oversight of the Faculty's professional placement courses and the integration of work-integrated learning within the broader academic curriculum in the Faculty.

Gretchen Kerr is a full professor and acting dean in the Faculty of Kinesiology and Physical Education at the University of Toronto. In her role, she is responsible for providing leadership and oversight of the development, management, coordination, accreditation and evaluation of all undergraduate and graduate degree programs of the Faculty. Gretchen also has an extensive publication record, with numerous peer-reviewed journal articles and book chapters.

Ellen MacPherson is a PhD candidate in sport psychology in the Faculty of Kinesiology and Physical Education at the University of Toronto. Ellen's research interests broadly explore peer relationships in the sport context, including the influence of peers on psychosocial development and experiences of offline and online bullying amongst sport peers. Ellen's other research interests include exploring athlete welfare and enhancing safeguarding practices in organized sport environments.

Jenessa Banwell is a PhD candidate in the Faculty of Kinesiology and Physical Education at the University of Toronto. She has experience in the study of experiential education and work-integrated learning and has worked with the Higher Education Quality Council of Ontario in enhancing the educational quality of these particular fields in higher education.

Ahad Bandealy is a researcher in the second year of a $\mathrm{PhD}$ program in the Faculty of Kinesiology and Physical Education at the University of Toronto. Originally from Florida, Ahad received a BSc in psychology from Bethune-Cookman University in Daytona Beach, Florida. He completed a MSc at the University of Toronto, and his work has and continues to focus on maltreatment in sport. 
Anthony Battaglia is a first-year doctoral student in the Department of Exercise Sciences at the University of Toronto, studying in the field of sport psychology. His thesis, Youth Athletes' Interpretations of Punishment in Hockey, was funded by the 2014-2015 Joseph A. Bombardier CGS. Anthony's research interests involve examining coaching practices commonly used in sport and youth athletes' sport experiences. 